\title{
Epithelial Progenitors in the Normal Human Mammary Gland
}

\author{
John Stingl, ${ }^{1,2}$ Afshin Raouf, ${ }^{1}$ Joanne T. Emerman, ${ }^{3}$ and Connie J. Eaves ${ }^{1,4}$
}

\begin{abstract}
The human mammary gland is organized developmentally as a hierarchy of progenitor cells that become progressively restricted in their proliferative abilities and lineage options. Three types of human mammary epithelial cell progenitors are now identified. The first is thought to be a luminal-restricted progenitor; in vitro under conditions that support both luminal and myoepithelial cell differentiation, this cell produces clones of differentiating daughter cells that are exclusively positive for markers characteristic of luminal cells produced in vivo (i.e., keratins 8/18 and 19, epithelial cell adhesion molecule [EpCAM] and MUC1). The second type is a bipotent progenitor. It is identified by its ability to produce "mixed" colonies in single cell assays. These colonies contain a central core of cells expressing luminal markers surrounded by cells with a morphology and markers (e.g., keratin $14^{+}$) characteristic of myoepithelial cells. Serial passage in vitro of an enriched population of bipotent progenitors promotes the expansion of a third type of progenitor that is thought to be myoepithelialrestricted because it only produces cells with myoepithelial features. Luminal-restricted and bipotent progenitors can prospectively be isolated as distinct subpopulations from freshly dissociated suspensions of normal human mammary cells. Both are distinguished from many other cell types in mammary tissue by their expression of EpCAM and CD49f ( $\alpha 6$ integrin). They are distinguished from each other by their differential expression of MUC1, which is expressed at much higher levels on the luminal progenitors. To relate the role of these progenitors to the generation of the three-dimensional tubuloalveolar structure of the mammary tree produced in vivo, we propose a model in which the commitment to the luminal versus the myoepithelial lineage may play a determining role in the generation of alveoli and ducts.
\end{abstract}

KEY WORDS: mammary stem cells; colony assays; flow cytometry; cell culture.

\section{INTRODUCTION}

The mammary gland is a compound tubuloalveolar gland embedded within an irregular connective tissue. Milk is synthesized within the distally located differentiated acini of the gland and then

\footnotetext{
${ }^{1}$ Terry Fox Laboratory, British Columbia Cancer Agency, Vancouver, British Columbia, Canada.

${ }^{2}$ StemCell Technologies Inc., Vancouver, British Columbia, Canada.

${ }^{3}$ Department of Anatomy and Cell Biology, University of British Columbia, Vancouver, British Columbia, Canada.

${ }^{4}$ To whom correspondence should be addressed at the Terry Fox Laboratory, 601 West 10th Avenue, Vancouver, British Columbia, Canada V5Z 1L3. e-mail: ceaves@bccrc.ca.
}

carried proximally through a series of ramified ducts to the nipple (1). The smallest ducts, the intralobular ducts, together with clusters of alveoli, form the lobules or terminal ductal lobular units (TDLUs).

\footnotetext{
Abbreviations used: EpCAM, epithelial cell adhesion molecule; TDLU, terminal ductal lobular unit; TEB, terminal end bud; SMA, smooth muscle actin; SLC, small light cell; K, keratin; MaSC, mammary stem cell; HMEC, human mammary epithelial cell; Ma-CFC, mammary colony-forming cell; Ma-CFC$\mathrm{Lu}$, luminal-restricted progenitor; Ma-CFC-Me, myoepithelialrestricted progenitor; Ma-CFC-LuMe, bipotent progenitor; CALLA, common acute lymphoblastic leukemia antigen; ESA, epithelial specific antigen; BGA2, histo-blood group antigen $\mathrm{H}$ type 2; EGF, epidermal growth factor; FACS, fluorescenceactivated cell sorting.
} 
Mammary parenchyma is composed primarily of two types of differentiated epithelial cells. Luminal cells are cuboidal/columnar cells that line both the ducts and alveoli. During lactation, the luminal cells within the distal ducts and alveoli initiate milk production and are called alveolar cells. Myoepithelial cells are specialized contractile epithelial cells that are situated between the luminal cells and the basement membrane. In the ducts, myoepithelial cells form a continuous sheath. In the alveoli, their distribution is sparser and their cytoplasmic processes create a looser, basket-like structure that allows some luminal cells to come in contact with the basement membrane (2).

In females, after the full development of the mammary tree is completed during puberty, cyclical bursts of proliferation (and apoptosis) recur during each menstrual cycle and also following the onset of pregnancy (3). Thus, it may be inferred that the mammary gland maintains functionally intact, exogenously regulated progenitor populations throughout adult female life. Numerous studies have studied the proliferating cells in the mammary epithelium (4-11). These have generally shown that cell divisions are most prevalent amongst the luminal cells, although a low rate of cell division within the basal cell subpopulation is also observed.

Differentiated luminal and myoepithelial cells account for $>90 \%$ of the epithelial cells present in the mammary gland (9). However, occasional cells with an undifferentiated morphology have also been recognized, and these have been considered as candidates for cells that have progenitor activities. One example is the so-called "cap" cell that lines the terminal end buds (TEBs) of elongating ducts and is exclusive to these structures $(12,13)$. Cap cells have a phenotype that is intermediate between luminal and myoepithelial cells, as indicated by a shared, albeit low level expression of markers associated with both lineages (e.g. vimentin, smooth muscle actin (SMA) and MUC1). Some investigators $(12,13)$ have therefore suggested that cap cells are uncommitted mammary epithelial "stem" cells. However, an alternative concept is that these cap cells simply represent myoepithelial progenitors that are responsible for ductal elongation (14).

Another morphologically defined candidate stem cell is the "small light" cell (SLC) (9). Chepko and Smith performed an exhaustive electron microscopic study of the resting mouse and rat mammary epithelium. Based on the mitotic pairs identified, they proposed a hierarchy of 3 division-competent, morphologically distinct cell populations. The most primitive of these was a basally-positioned, putative stem cell present at a frequency of $3 \%$ until senescence, by which time these cells disappeared (15). Other morphologically defined cell types considered as candidate mammary stem cells include basal clear cells (5) and the keratin $19^{-}\left(\mathrm{K} 19^{-}\right)$epithelial cells found within the luminal layer in vivo (16). The latter were postulated to be stem cells because of their greater frequency in small ducts and lobules, their lack of casein production and the fact that their presence could be associated with sites of more active proliferation during pregnancy. However, all of these studies are compromised by their intrinsically limited correlative nature and inability to definitively associate a particular cell phenotype with its progeny output potential.

Transplantation of mammary cells into cleared mammary fat pads has been used as a functional approach to identify mammary epithelial cells with stem cell properties $(5,17)$. These experiments laid the foundation of the concept of mammary epithelial stem cells (MaSCs), although the single-cell origin of the structures obtained still remained to be established. This verification was subsequently provided by studies of transplants of cells at limiting dilutions, which allowed the clonal nature of the regenerated alveolar, ductal and more complex structures to be confirmed $(18,19)$. These findings further introduced the concept of alveolar-restricted and ductalrestricted as well as pluripotent MaSCs in the adult mouse mammary gland. This assay has also been used to show that MaSCs are present throughout the murine mammary tree, with the highest frequency of MaSCs in the end buds and the lowest frequency of MaSCs in lactating alveoli (5). More recently, the cleared mammary fat pad assay has been successfully used to characterize the phenotype of MaSCs in single cell suspensions of mouse mammary epithelial cells (20) and to obtain highly enriched populations of these cells (21). These studies have confirmed the presence in the adult mouse mammary gland of pluripotent, self-renewing MaSC populations that are largely separable from other progenitors detectable by their ability to make colonies of differentiating cells in vitro (Stingl et al., manuscript in preparation) and strongly imply the existence of a similar hierarchy in human mammary tissue.

However, the development of an analogous methodology for identifying and characterizing stem cells within human mammary epithelium has been more difficult due to the challenges of developing 
a suitable in vivo xenotransplant assay. Therefore, in the human arena, greater effort has been placed on attempts to optimize conditions for supporting the growth and differentiation of primitive human mammary epithelial cells (HMECs) seeded at clonal densities in vitro (22-31). This strategy has led to the development of methods for identifying multiple subpopulations of HMEC progenitors, including a multi-potent HMEC with self-renewal ability (30). Here we will focus on the HMECs that form adherent colonies of exclusively luminal or myoepithelial cells or mixtures of these differentiated cellular phenotypes in vitro.

\section{DEFINITIONS AND NOMENCLATURE}

The defining features of a stem cell are its ability to generate differentiated progeny for the lifetime of the organism. This definition, in turn, usually implies an ability to generate progeny with the same, often multipotent, developmental potential. Since single mammary cells with an ability to renew their luminal and myoepithelial differentiation activity have now been identified in both mice and humans using several methodological approaches, it seems useful to limit the term MaSCs to cells that are shown to have such properties. MaSCs are then distinguished functionally from HMEC progenitors, which are simply defined by their ability to generate more than some minimal number of progeny of one or more lineages. Here we describe assays for HMEC progenitors that generate colonies containing at least four cells (i.e. undergo a minimum of two cell divisions) within 7 days in vitro and produce progeny that show exclusive evidence of luminal differentiation, myoepithelial differentiation, or both (see markers described below). Accordingly, as a group, the progenitors of these colonies are referred to as mammary colonyforming cells (Ma-CFCs) and the respective subsets as Ma-CFC-Lu, Ma-CFC-Me and Ma-CFC-LuMe. This adoption of operationally defined nomenclature minimizes the type of confusion that arises, for example, from referring to luminal cells as epithelial cells.

\section{CHARACTERIZATION OF MAMMARY CELL LINEAGES FROM IN VIVO STUDIES}

Human mammary epithelium has now been analyzed for patterns of expression of a large number of proteins (Table I). SMA (32), keratin 14 (K14)
Table I. In Vivo Distribution of Markers Commonly Used to Characterize HMECs

\begin{tabular}{|c|c|c|}
\hline Marker & Distribution in vivo & Reference \\
\hline SMA & Myoepithelial & (32) \\
\hline CD10/CALLA & Basal & (33) \\
\hline $\begin{array}{l}\text { CD49f } \\
\quad(\alpha 6 \text { integrin })\end{array}$ & Basal + endothelial & (34) \\
\hline p63 & Basal & $(35)$ \\
\hline Vimentin & Basal and stromal & (36) \\
\hline CD44v6 & Basal & (37) \\
\hline K14 & $\mathrm{Basal}^{a}$ & (38) \\
\hline K18 & Luminal $^{b}$ & (38) \\
\hline K19 & Some luminal & $(38)$ \\
\hline $\mathrm{CD} 24$ & Apical surfaces of luminal cells & (39) \\
\hline CD133 & Apical surfaces of luminal cells & $(40)$ \\
\hline MUC1 & Apical surfaces of luminal cells & (41) \\
\hline EpCAM & All cells except myoepithelial & $(25,42)$ \\
\hline ErbB2 & All cells except myoepithelial & (43) \\
\hline
\end{tabular}

${ }^{a}$ Also expressed by some luminal positioned cells in the large ducts (44).

${ }^{b}$ Many luminal-positioned cells in large ducts do not express K18 (45).

(38), CD10 (common acute lymphoblastic leukemia antigen; CALLA) (33), CD49f ( $\alpha 6$ integrin) (34), p63 (35), CD44v6 (37) and the intermediate filament vimentin (36) are generally localized to cells found in the basal cell layer of the normal human adult mammary epithelium. Exceptions to this list include expression of K14 in luminal cells in the large ducts (44) and expression of vimentin in fibroblasts found in the stroma that surround the actual mammary parenchyma (46). Markers useful for identifying luminal cells based on their consistent staining pattern in vivo include keratin 18 (K18) (38), K19 (38), CD24 (39), CD133 (40; unpublished observations) and MUC1 (41). However, lack of expression of K18/K19 by some luminal cells has been noted $(16,45)$. These aberrant cells are found as isolated cells or small clusters of cells within small ducts and TDLUs.

MUC1 is a highly glycosylated apical plasma membrane protein characterized by variable numbers of tandem repeats (41). Considerable heterogeneity in the MUC1 epitopes expressed on different luminal cells in vivo has been revealed by comparing immunostaining results with different anti-MUC1 antibodies $(26,47)$. Hence particular care should be used in identifying the antibody preparation used before interpreting MUC1 expression data. Epithelial cell adhesion molecule (EpCAM; also known as epithelial specific antigen or ESA), is a homophilic 
$\mathrm{Ca}^{2+}$-independent cell adhesion molecule specific for most epithelial cells $(42,48)$. EpCAM in normal adult mammary tissue is localized primarily to the basal and lateral cell membranes of luminal epithelial cells $(25,42)$. Stromal cells and myoepithelial cells do not express this protein (48-49). ErbB2 expression shows a similar distribution to EpCAM, with strongest expression on the luminal cells, weak-to-no expression by the myoepithelial cells and no expression by the stromal cells (43). Care should be taken in the interpretation of erbB2 immunostaining patterns since erbB2 can exist in two different forms (apical and basolateral) with different antibodies recognizing the different erbB2 forms (50).

\section{CHARACTERIZATION OF HMEC-DERIVED COLONIES}

Normal human mammary tissue (obtained from discarded reduction mammoplasty specimens) can be enzymatically dissociated and filtered to obtain a suspension of viable single cells (51). When these are cultured at clonal densities $\left(<500\right.$ cells $\left./ \mathrm{cm}^{2}\right)$ in a serum-free but growth factor-supplemented medium on an irradiated mouse fibroblast feeder layer (NIH $3 \mathrm{~T} 3$ cells), $\sim 1 \%$ of the HMECs will form a colony of $>4$ cells within a week. The cloning efficiency increases $\sim$ fivefold after the cells have been "precultured" a short period (2-6 days) prior to performing the CFC assays. The increased frequency is likely due to the selective loss during the first several days in culture of nonepithelial cells and terminally differentiated HMECs present in the original suspension. Interestingly, the average frequency of Ma-CFCs has not been found to be associated with donor age $(28,31,52)$. HMEC progenitors will typically divide up to a maximum of 20 times before they senesce $(28,53)$. As senescence becomes imminent, the cells become large, flattened and vacuolated. In cultures of HMECs maintained in serum-free conditions, the proportion of cells exhibiting a myoepithelial phenotype typically increases, with a concomitant loss of cells having a luminal phenotype.

When cells are plated under conditions that support the proliferation and differentiation of Ma-CFCs, a spectrum of different colony types is produced after 6-10 days of incubation. Figure 1 shows examples of the three categories to which these are assigned depending on the prevalence of luminal and myoepithelial cell types present: pure luminal cell (Fig. 1(A) and (B)), pure myoepithelial cell (Fig. 1(C)) and mixed phenotype containing both luminal and myoepithelial cells (Fig. 1(D)-(F)). Individual colonies within each subtype may show considerable variation in size. The majority $(\sim 80 \%)$ of the colonies obtained in colony assays initiated with minimally cultured HMEC have a mixed phenotype, whereas most of the remaining colonies are pure luminal cell colonies (28).

Pure luminal cell colonies are characterized by a tight arrangement of the cells they contain and have indistinct cell borders and a smooth outer colony boundary. In the smaller colonies, the cells form tightly arranged clumps that give the appearance of rounded spherical structures (Fig. 1(A)), whereas in the larger ones (Fig. 1(B)), the cells at the periphery appear more tightly arranged than those located at the center of the colony. Most of the cells within these colonies express MUC1, K8/18, EpCAM and $\mathrm{K} 19$, and do not express K14, CD44v6 and histo blood group antigen $\mathrm{H}$ type 2 (BGA2; 28,54,55). It is interesting to note that K19 is consistently expressed in these colonies $(28,49,54)$, even though K19 is not a reliable marker of luminal epithelial cells in vivo (16). Cells having a luminal phenotype can be induced to further differentiate into casein-producing cells by the addition of fresh culture medium supplemented with of $1 \mu \mathrm{g} / \mathrm{mL}$ ovine prolactin and $50 \%$ Matrigel (30).

Pure myoepithelial cell colonies contain a dispersed arrangement of cells with a characteristic elongated shape (Fig. 1(C)). The dispersal of cells in these colonies reflects the ability of myoepithelial cells to migrate in response to stimulation by epidermal growth factor (EGF) present in the culture medium (28). The cells in these colonies express K14, BGA2, CD44v6, CD49f and CD10, but not MUC1, EpCAM and K19 $(23,28,30,55)$. However, they often fail to express SMA, a component inversely associated with the growth status of myoepithelial cells (56).

Mixed lineage colonies typically contain a central core of cells similar to those found in pure luminal colonies (close cell arrangement expressing MUC1, EpCAM and K19, and lack of expression of K14 and BGA2) and are surrounded by a halo of highly refractile, migratory elongated cells (Fig. 1 (D-F)) similar to those found in pure myoepithelial colonies (expressing K14, BGA2, and CD44v6, but not MUC1, EpCAM and K19) $(25,28,55)$. Interestingly, many of the $\mathrm{K} 14^{+}$elongated cells adjacent to the central core also express K18, a marker traditionally considered to be specific for luminal cells in vivo 


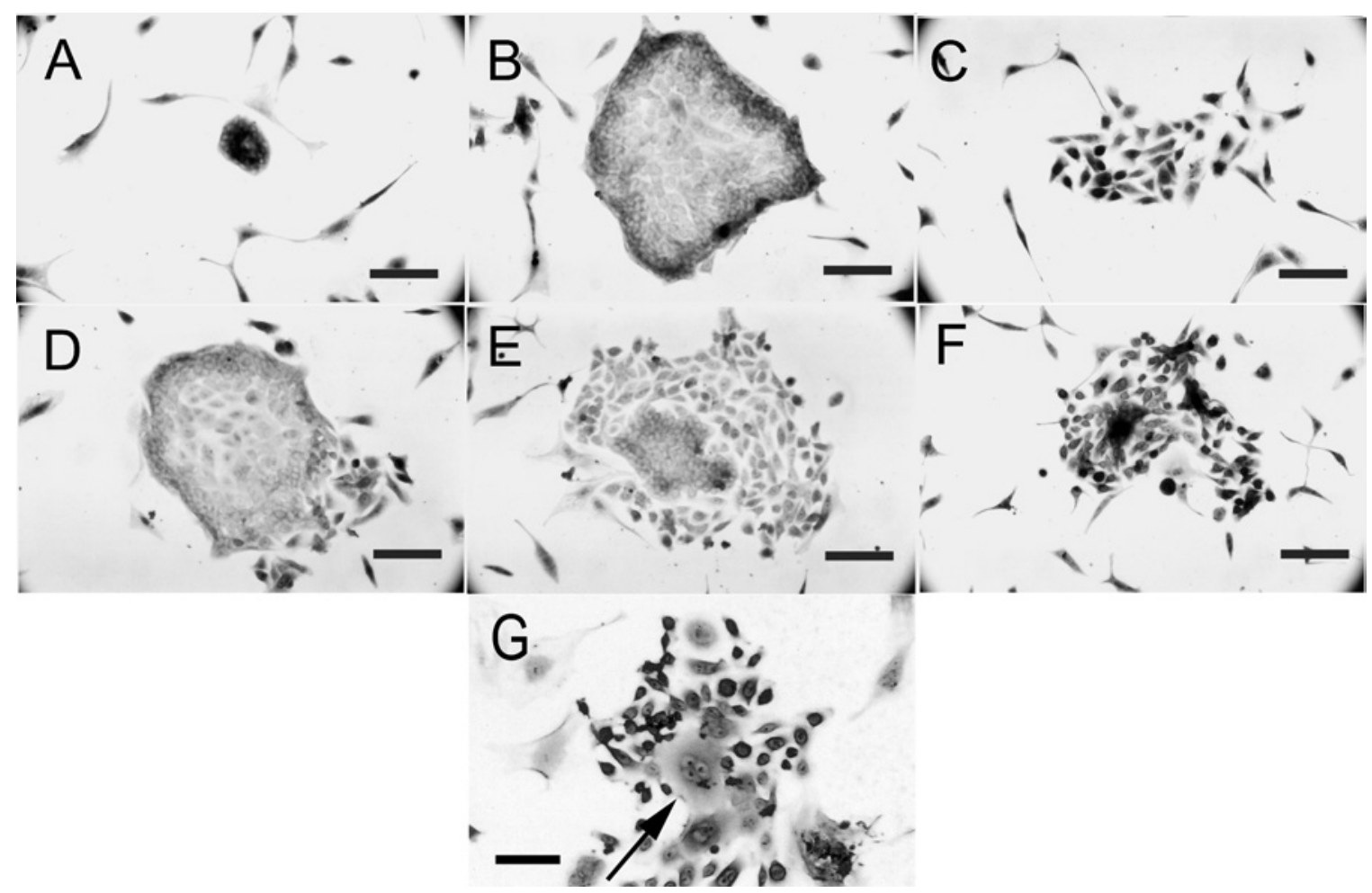

Fig. 1. Range of HMEC colony morphologies observed after 7-10 days in serum-free culture. All colonies in Panels A-F were generated from the same original primary HMEC culture. Colony phenotypes include pure luminal (A-B), pure myoepithelial (C) and mixed (D-F). In some of the mixed and pure myoepithelial cell colonies, the centrally located cells have a squamous morphology and are often multinucleated (arrow in G). Bar $=250 \mu \mathrm{m}$.

(38). Similar $\mathrm{K} 14^{+} / \mathrm{K} 18^{+}$cells have been described by others $(31,54)$ and may represent a morphological intermediate in the generation of myoepithelial cells from a more primitive cell type. Mixed colonies do not represent an artifact of co-plated doublets with different lineage potentialities, as proven by experiments with single cell cultures $(28,31)$.

The centrally located cells in the mixed and pure myoepithelial cell-containing colonies occasionally exhibit a squamous phenotype (Fig. $1(\mathrm{G})$, arrow), a phenomenon associated with the presence of cholera toxin in the culture medium, cell proliferation and the menstrual cycle status of the individual from whom the sample was obtained $(13,22$, 57). Cells derived from women who are in the late stages of the menstrual cycle are more susceptible to squamous metaplasia than those in the early stages of the cycle. The centrally located cells in such colonies, particularly when they have a squamous phenotype, are sometimes multinucleated (Fig. 1(G), arrow). The generation of multinucleated mammary epithelial cells has been associated with bypassing "senes- cence" or "selection," having a methylated p $16^{\mathrm{INK} 4 \mathrm{~A}}$ promoter, eroding telomeric sequences and a susceptibility to acquire further genomic abnormalities $(53,58)$.

\section{CHARACTERIZATION OF HMEC PROGENITORS}

Flow cytometry has been used extensively to characterize the phenotype of CFC-Lu's and CFC-LuMe's progenitors, particularly from HMECs obtained from 2-6-day cultures of dissociated human mammary organoids. As summarized in Table II, this research has shown that most CFC-Lu's have a $\mathrm{MUC1}^{+} / \mathrm{CD}_{133}{ }^{+} / \mathrm{EpCAM}^{+} / \mathrm{CD} 49 \mathrm{f}^{+} / \mathrm{CD} 10^{-} / \mathrm{Thy}^{-}$ phenotype and most CFC-LuMe's have a $\mathrm{MUC1}^{-} / \mathrm{CD} 133^{-} / \mathrm{EpCAM}^{+} / \mathrm{CD} 49 \mathrm{f}^{+} / \mathrm{CD} 10^{+} / \mathrm{Thy}^{+}$ phenotype $(25,28$; unpublished observations). In some freshly isolated cell suspensions, the CFCs are found to be distributed between the $\mathrm{EpCAM}^{+}$ and $\mathrm{EpCAM}^{-}$fractions (unpublished observations); 
Table II. Phenotypic Profiles of Human Mammary Epithelial Progenitor and Nonprogenitor Populations

\begin{tabular}{lcccc}
\hline & \multicolumn{4}{c}{ CFC-LuMe/ Nonclonogenic } \\
Marker & CFC-Lu & Me & $\begin{array}{c}\text { Cultured } \\
\text { luminal }\end{array}$ & myoepithelial \\
\hline MUC1 & + & - to \pm & + & - \\
CD133 & + & - & & - \\
EpCAM & + & $-{ }^{a}$ & + & \\
CD49f & + & + & - & \\
CD10 & - & + & - & + \\
Thy1 & - & + & - & + \\
BGA2 & & & & \\
CD44v6 & & & & \\
ErbB2 & + & + & + & \\
\hline
\end{tabular}

${ }^{a}$ When using precultured material.

however, after a few days in culture all of the CFCs detected are $\mathrm{EpCAM}^{+}$. By combining immunomagnetic enrichment and multi-parameter fluorescence-activated cell sorting (FACS), CFCLu's and CFC-LuMe's can be isolated at purities of $\sim 30$ and $\sim 50 \%$ respectively (unpublished observations). The $\mathrm{MUC1}^{-} / \mathrm{CD} 49 \mathrm{f}^{+} / \mathrm{CD} 10^{+}$phenotype of CFC-LuMe's suggests that these cells are basally positioned in vivo. This prediction is further supported by immunocytochemical studies of human mammary tissue sections, which have revealed the presence of $\mathrm{MUC1}^{-} / \mathrm{EpCAM}^{+}$cells in the basal layer of the epithelium (29).

Isolation of the $\mathrm{EpCAM}^{+} / \mathrm{CD} 4 \mathrm{f}^{-}$fraction yields a population of HMECs that are depleted of CFCs, although in culture loss of either CD49f or EpCAM was found to correlate with decreased CFC activity (28). This scenario is likely associated with the terminal differentiation of HMECs along the luminal and myoepithelial pathways, respectively.

\section{COMPARISON OF MA-CFCs FROM HUMANS AND RODENTS}

Several reports have described the presence of CFCs in both mouse and rat mammary cell populations (59-61). Direct comparisons between colonies and CFCs of human and rodent origin is confounded by the different culture conditions and antibodies used for their characterization. Nevertheless, some generalizations can be made. For example, Ma-CFCs from rodent sources appear to make the same three categories of colonies as their human counterparts; i.e., pure luminal colonies and pure myoepithelial colonies as well as mixed colonies containing dif- ferentiated cells of both lineages. However, murine progenitors of mixed colonies expressed phenotypic markers shared by luminal cells (mouse milk fat globule membrane antigen), which contrasts with the finding for human CFC-LuMe's that were not found to express markers present at the apical plasma membrane (MUC1 and CD133). Clearly more extensive profiling of these different progenitors from human and rodent sources will be needed to determine the extent of similarity between currently defined compartments.

\section{INTERPRETING COLONY ASSAY DATA}

There are several points to be kept in mind when interpreting results of in vitro colony assays. First and foremost, although MaSCs may be detectable as CFCs, it is unlikely that all CFCs are MaSCs. In particular, CFCs that display restricted differentiation potentialities and have associated distinct phenotypes are most likely to represent derivative progenitor populations. Not even all bipotent CFCs are likely to be MaSCs if, as in other systems, lineage restriction is a progressive process that can span multiple cell generations.

Another point to be emphasized is that the number and types of cells produced are highly dependent on the culture conditions used. For example, assays of human Ma-CFCs that contain human mammary fibroblasts rather than irradiated NIH 3T3 cells increases the frequency of pure myoepithelial cell colonies and concomitantly reduces the yield of mixed cell colonies $(26,31)$. Altering components of the medium can similarly alter the balance of mature cell types generated, resulting in an apparent shift in the types of CFCs thought to be present originally (unpublished observations).

At present it is not known whether culture conditions that have been optimized to detect different types of Ma-CFCs also support the expansion or even maintenance of human MaSCs. In fact there are several lines of evidence to indicate that this is not the case. First, HMECs maintained in vitro only undergo 10-20 cell divisions before they senesce $(28,53)$. This number of divisions is well below the theoretical number of divisions thought to be permissible before telomeric degradation would be limiting and also well below the cell amplification obtained when murine MaSCs are sequentially propagated in cleared fat pads (19). Secondly, HMECs cultured in serum-free media eventually select for cells with a 
myoepithelial phenotype $(49,62,63)$. This rapid depletion of luminal cells within the population is not an intrinsic property of the cells since maintenance of HMECs in the presence of HGF, stromal feeders or serum will permit the maintenance of $\mathrm{K} 18^{+} / \mathrm{K} 19^{+}$ cells $(23,27,49,62,64)$. It is thus possible that serum is required for the sustained maintenance of more primitive types of HMECs, as appears to be the case for human epidermal cells (65). Thirdly, stem cells from many tissues are known to be difficult to maintain in vitro, and particularly to expand, in the absence of genetic intervention $(66,67)$. Factors implicated in the maintenance of adult tissue stem cells in vitro include guanine nucleotide pools (68), culture substratum $(65,69,70)$, anchorage-independent conditions $(30,71-73)$, presence of serum (65) and factors that activate the Wnt signaling pathway (74). In addition, Ehmann and colleagues have demonstrated that rat $\mathrm{K} 14^{+} / \mathrm{K} 18^{-}$mammary LA7cells can maintain primary mouse mammary $\mathrm{K} 8^{+} \mathrm{K} 18^{+}$cells for at least 30 population doublings (75), thus raising the possibility that epithelial feeders may be essential for stimulating MaSC self-renewal divisions in vitro. Interactions between luminal and myoepithelial cells have been demonstrated to be important regulators of epithelial cell polarity (76) and epithelial branching morphogenesis (77) via laminin-1 and epimorphin production by myoepithelial cells, respectively. It is possible that similar interactions between different subtypes of epithelial cells play a role in maintaining the MaSC niche.

\section{HIERARCHICAL ORGANIZATION OF HMEC'S AND THE DEVELOPMENT OF ORGANIZED MAMMARY TISSUE IN VIVO}

Figure 2 presents a schematic representation of the hierarchical organization proposed for HMEC differentiation from a putative MaSC. Assuming that the majority of the progenitors detected in Ma-CFC assays are not MaSCs, CFC-LuMe's would be positioned as their downstream progeny and CFC-Lu's and CFC-Me's as derivatives fully committed to a single lineage. Consistent with this analysis are the findings that CFC-Lu's generate limited numbers, but exclusively CFC-Lu's when replated; the same is true for CFC-Me's (22,29; unpublished observations). On the other hand, this argument is weakened by the fact that CFC-LuMe's fail to generate detectable numbers of either CFC-LuMe's or CFC-Lu's upon replating, suggesting, as discussed above, that the earliest

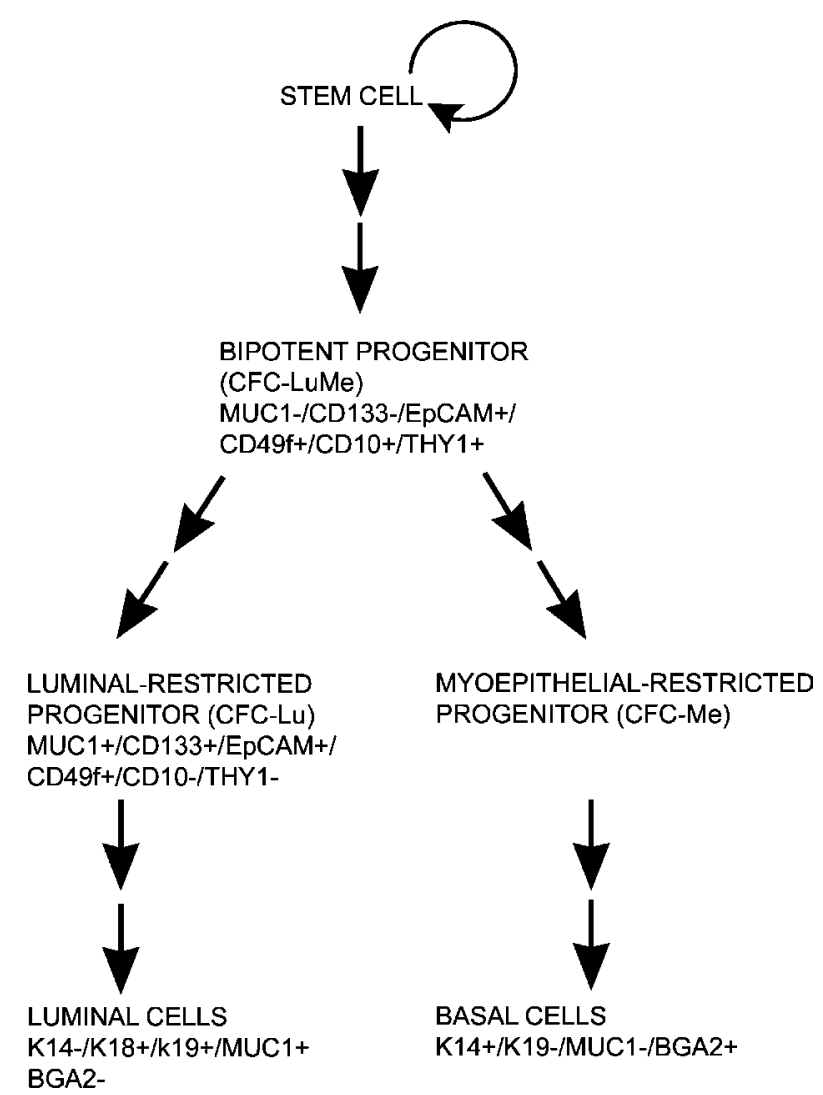

Fig. 2. Proposed hierarchical arrangement of mammary epithelial progenitors.

steps of HMEC development in vitro are not as robust as would be desirable.

The hierarchical schema proposed in Fig. 2 does not, of course, address the question of how these cells generate the three-dimensional mammary tree in vivo that consists of organized ducts and lobules or how they may relate to the transplantable ductal- and lobular-restricted mammary progenitors described in the mouse using the cleared mammary fat assay $(18,19)$. Early studies examining the serial transplantation of mouse mammary tissue demonstrated that ductal development decreased with mitotic age of the transplanted cells and not the chronological age of the host $(17,78)$. No in vivo data are yet available to make similar assessments of primitive HMECs, although results obtained from plating purified human CFC-Lu's and CFC-LuMe's in three-dimensional matrices may provide some clues. These experiments have demonstrated the formation of colonies that have gross morphologies that resemble alveoli and ducts, respectively $(28,29,79)$. 


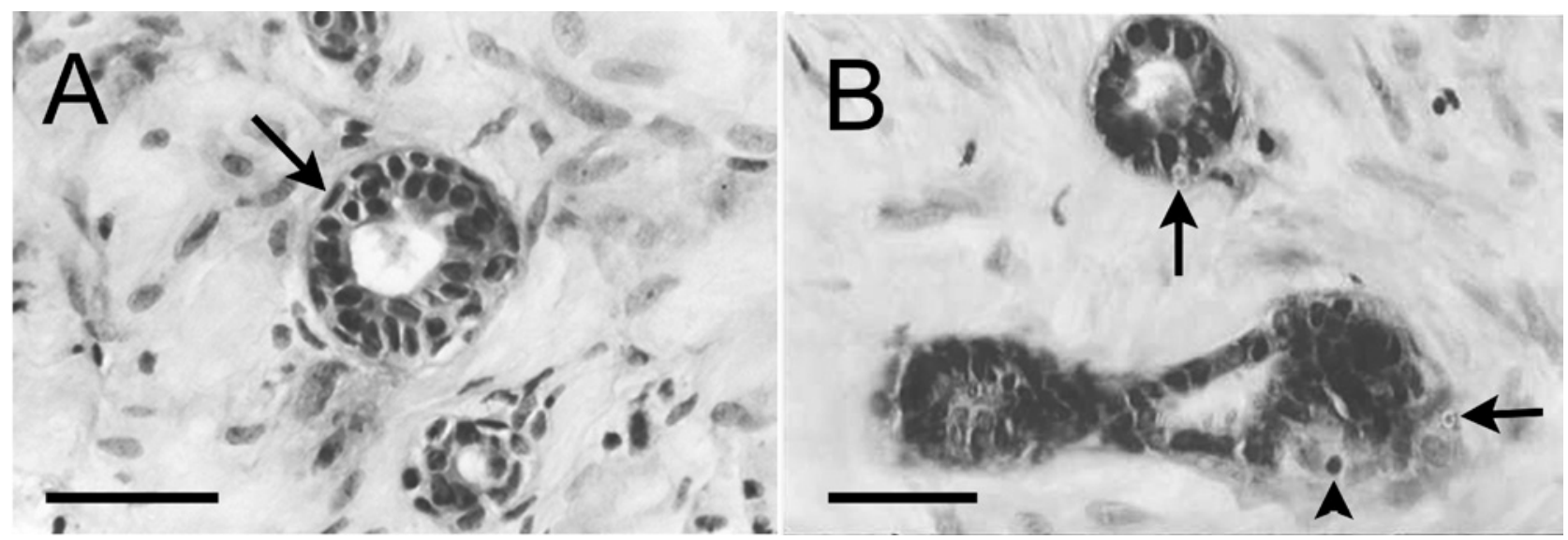

Fig. 3. Epithelial outgrowths observed after 4 weeks in vivo when single-cell suspensions of HMEC are engrafted within human mammary fibroblast-containing collagen gels under the renal capsule of female NOD/SCID mice supplemented with exogenous estrogen and progesterone. Note the presence of a stratified epithelium composed of a luminal cell layer and a myoepithelium (arrow in A). Also present are basal clear cells (arrowhead in B) and cells with a SLC morphology (arrows in B). Bar $=50 \mu \mathrm{m}$.

Thus a simple model to explain the generation of the mammary tree is that CFC-Lu's represent alveolar progenitors and CFC-LuMe's represent ductal progenitors. In the mixed colonies, cells expressing luminal cell characteristics surrounded by cells expressing myoepithelial cell characteristics are consistently observed $(25,27,28,30,31)$, an arrangement that mirrors that observed in vivo.

An alternative possibility is that the type of outgrowth generated in vivo is simply a reflection of the ratio of cells acquiring luminal and myoepithelial fates, and that these may be prefixed or externally controlled in MaSCs. For example, in the presence of factors that promote ductal elongation (i.e., estrogen; 80 ), there may be an increased production of myoepithelial cells (31) whose migratory abilities pave the way for ductal elongation. Likewise, in a time when many differentiated luminal cells are required (during pregnancy and lactation), a shift towards the production of luminal cells could be induced. The concept of a controlled balance between luminal and myoepithelial commitment has been entertained for many years by Rudland and colleagues (reviewed in 13).

\section{FUTURE DIRECTIONS}

Taken together, current findings suggest a common origin of HMECs and most presently detectable CFCs from a more primitive and distinct bipotent MaSC with extensive regenerative ability.
Preliminary experiments in which single cell suspensions of normal HMECs have been placed in collagen gels under the kidney capsule of immunodeficient NOD/SCID mice, as first described using tissue fragments (81), may now allow such a cell to be identified and characterized. Figure 3 shows an example of the type of regenerated normal human mammary cell structures that can be obtained using this approach. Future experiments using this methodology should help to answer many of the questions raised in this chapter and set the stage for understanding the relationships between primitive normal HMECs and their various malignant $\left(\mathrm{EpCAM}^{+} / \mathrm{CD} 24^{-} / \mathrm{CD} 44^{+}\right)$counterparts (82-84).

\section{ACKNOWLEDGMENTS}

The authors thank Mrs Darcy Wilkinson for technical assistance and Drs Patty Clugston, Jane Sproul, Peter Lennox and Richard Warren for assistance in obtaining surgical specimens. The work of the authors described was supported by grants from the Canadian Breast Cancer Research Initiative of the National Cancer Institute of Canada, the Stem Cell Network and Genome BC/Canada. J. Stingl has held Postdoctoral Fellowships from the Canadian Breast Cancer Foundation (BC/Yukon Chapter) and the Natural Sciences and Engineering Research Council of Canada. A. Raouf held Postdoctoral Fellowships from the Canadian Breast Cancer 
Foundation (BC/Yukon Chapter) and the Canadian Institutes of Health Research.

\section{REFERENCES}

(1) Russo J, Russo IH. Development of the human mammary gland. In: Neville MC and Daniel CW, editors. The mammary gland: Development, regulation and function. New York (NY): Plenum; 1987. p. 67-93.

(2) Emerman JT, Vogl AW. Cell size and shape changes in the myoepithelium of the mammary gland during differentiation. Anat Rec 1986;216:405-15.

(3) Anderson TJ, Ferguson DJP, Raab GM. Cell turnover in the "resting" human breast: Influence of parity, contraceptive pill, age and laterality. Br J Cancer 1982;46:37682.

(4) Joshi K, Smith JA, Perusinghe N, Monoghan P. Cell proliferation in human mammary epithelium. Differential contribution by epithelial and myoepithelial cells. Am J Pathol 1986;124:199-206.

(5) Smith GH, Medina D. A morphologically distinct candidate for an epithelial stem cell in the mouse mammary gland. J Cell Sci 1988;89:173-83.

(6) Ferguson DJP. An ultrastructural study of mitosis and cytokinesis in normal "resting" human breast. Cell Tissue Res 1988;252: 581-87.

(7) Sapino A, Macri L, Gugliotta P, Bussolati G. Immunocytochemical identification of proliferating cell types in mouse mammary gland. J Histochem Cytochem 1990;38:154147.

(8) Perusinghe NP, Monaghan P, O'Hare MJ, Ashley S, Gusterson BA. Effects of growth factors on proliferation of basal and luminal cells in human breast epithelial explants in serum-free culture. In Vitro Cell Dev Biol 1992;28A:9096.

(9) Chepko G, Smith GH. Three division-competent, structurally-distinct cell populations contribute to murine mammary epithelial renewal. Tissue Cell 1997;29:239-53.

(10) Zeps N, Bentel JM, Papadimitriou JM, D'Antuono MF, Dawkins HJ. Estrogen receptor-negative epithelial cells in mouse mammary gland development and growth. Differentiation 1998;62:221-26.

(11) Clarke RB, Howell A, Anderson E. Estrogen sensitivity of normal human breast tissue in vivo and implanted into athymic nude mice: Analysis of the relationship between estrogen-induced proliferation and progesterone receptor expression. Breast Cancer Res Treat 1997;45:121-33.

(12) Williams JM, Daniel CW. Mammary ductal elongation: Differentiation of myoepithelium and basal lamina during branching morphogenesis. Dev Biol 1983; 97:274-90.

(13) Rudland PS, Barraclough R, Fernig DG, Smith JA. Mammary stem cells in normal development and cancer. In: Potten C, editor. Stem cells. San Diego (CA): Academic Press; 1997. p. $147-232$.

(14) Sapino A, Macri L, Gugliotta P, Pacchioni D, Liu YJ, Medina D and Bussolati G. Immunophenotypic properties and estrogen dependency of budding structures in the developing mouse mammary gland. Differentiation 1993;55:1318.
(15) Smith GH, Strickland P, Daniel CW. Putative epithelial stem cell loss corresponds with mammary growth senescence. Cell Tissue Res 2002;310:313-20.

(16) Bartek J, Bartkova J, Taylor-Papadimitriou J. Keratin 19 expression in the adult and developing human mammary gland. Histochem J 1990;22:537-44.

(17) Daniel CW, DeOme KB, Young JT, Blair PB, Faulkin LJ. The in vivo life span of normal and preneoplastic mouse mammary glands: A serial transplantation study. Proc Natl Acad Sci USA 1968;61:52-60.

(18) Smith GH. Experimental mammary epithelial morphogenesis in an in vivo model: Evidence for distinct cellular progenitors of the ductal and lobular phenotype. Breast Cancer Res Treat 1996;39:21-31.

(19) Kordon EC, Smith GH. An entire functional mammary gland may comprise the progeny from a single cell. Development 1998;125:1921-30.

(20) Welm BE, Tepera SB, Venezia T, Graubert TA, Rosen JM, Goodell MA. Sca-1 (pos) cells in the mouse mammary gland represent an enriched progenitor cell population. Dev Biol 2002;245:42-56.

(21) Stingl J, Ricketson I, Choi D, Eaves CJ. Phenotypic characterization of mouse mammary stem and progenitor cells. Proc Am Assoc Cancer Res 2004;45:641-2.

(22) O'Hare MJ, Ormerod MG, Monaghan P, Lane EB, Gusterson BA. Characterization in vitro of luminal and myoepithelial cells isolated from the human mammary gland by cell sorting. Differentiation 1991;46:209-21.

(23) Kao CY, Nomata K, Oakley CS, Welsch CW, Chang CC. Two types of normal human breast epithelial cells derived from reduction mammoplasty: Phenotypic characterization and response to SV40 transfection. Carcinogenesis 1995;16:531-38.

(24) Kao CY, Oakley CS, Welsch CW, Chang CC. Growth requirements and neoplastic transformation of two types of normal human breast epithelial cells derived from reduction mammoplasty. In Vitro Cell Dev Biol Anim 1997;33:282-88.

(25) Stingl J, Eaves CJ, Kuusk U, Emerman JT. Phenotypic and functional characterization in vitro of a multipotent epithelial cell present in the normal adult human breast. Differentiation 1998;63:201-13.

(26) Stingl J, Eaves CJ, Emerman JT. Characterization of normal human breast epithelial cell subpopulations isolated by fluorescence-activated cell sorting and their clonogenic growth in vitro. In: Ip $\mathrm{M}$ and Asch BB, editors. Methods in mammary gland biology and breast cancer research. New York (NY): Kluwer Academic; 2000. p. 177-93.

(27) Matouskova E, Dudorkinova D, Krasna L, Vesely P. Temporal in vitro expansion of the luminal lineage of human mammary epithelial cells achieved with the $3 \mathrm{~T} 3$ feeder layer technique. Breast Cancer Res Treat 2000;60:241-49.

(28) Stingl J, Zandieh I, Eaves CJ, Emerman JT. Characterization of bipotent mammary epithelial progenitor cells in normal adult human tissue. Breast Cancer Res Treat 2001:67:93-109.

(29) Gudjonsson T, Villadsen R, Nielsen HL, Ronnov-Jessen L, Bissell MJ, Petersen OW. Isolation, immortalization, and characterization of a human breast epithelial cell line with stem cell properties. Gene Dev 2002;16:693-706.

(30) Dontu G, Abdallah WM, Foley JM, Jackson KW, Clarke MF, Kawamura MJ, Wicha MS. in vitro propagation and transcriptional profiling of human mammary stem/progenitor cells. Gene Dev 2003;17:1253-70. 
(31) Clayton H, Titley I, Vivanco MM. Growth and differentiation of progenitor/stem cells derived from the human mammary gland. Exp Cell Res 2004;297:444-60.

(32) Skalli O, Ropraz P, Trzeciak A, Benzonana G, Gillessen D, Gabbiani G. A monoclonal antibody against $\alpha$-smooth muscle actin: A new probe for smooth muscle differentiation. J Cell Biol 1986;103:2787-96.

(33) Gusterson BA, Monaghan P, Mahendran R, Ellis J, O'Hare MJ. Identification of myoepithelial cells in human and rat breasts by anti-common acute lymphoblstic leukemia antigen antibody A12. J Natl Cancer Inst 1986;77:343-49.

(34) Koukoulis GK, Virtanen I, Horhonen M, Laitinen L, Quaranta V, Gould VE. Immunohistochemical localization of integrins in the normal, hyperplastic, and neoplastic breast. Am J Pathol 1991;139:787-99.

(35) Batistatou A, Stefanou D, Arkoumani E, Agnantis NJ. The usefulness of p63 as a marker of breast myoepithelial cells. In Vivo 2003; 17:573-76.

(36) Guelstein VI, Tchypyscheva TA, Ermilova VD, Litvinova LV, Troyanovsky SM, Bannikov GA. Monoclonal antibody mapping of keratins 8 and 17 and of vimentin in normal human mammary gland, benign tumors, dysplasias and breast cancer. Int J Cancer 1988;42:147-53.

(37) Fox SB, Fawcett J, Jackson DG, Collins I, Gatter KC, Harris AL, Gearing A, Simmons DL. Normal human tissues, in addition to some tumors, express multiple different CD44 isoforms. Cancer Res 1994;54:4539-46.

(38) Taylor-Papadimitriou J, Stampfer M, Bartek J, Lewis A, Boshell M, Lane EB, Leigh IM. Keratin expression in human mammary epithelial cells cultured from normal and malignant tissue: Relation to in vivo phenotypes and influence of medium. J Cell Sci 1989;94:403-13.

(39) Jones C, Mackay A, Grigoriadis A, Cossu A, Reis-Filho JS, Fulford L, Dexter T, Davies S, Bulmer K, Ford E, Parry S, Budroni M, Palmieri G, Neville AM, O'Hare MJ, Lakhani SR. Expression profiling of purified normal human luminal and myoepithelial breast cells: Identification of novel prognostic markers for breast cancer. Cancer Res 2004;64:303745.

(40) Corbeil D, Roper K, Hellwig A, Tavian M, Miraglia S, Watt SM, Simmons PJ, Peault B, Buck DW, Huttner WB. The human AC133 hematopoietic stem cell antigen is also expressed in epithelial cells and targeted to plasma membrane protrusions. J Biol Chem 2000;275:5512-20.

(41) Taylor-Papadimitriou J, Burchell JM, Punkett T, Graham R, Correa I, Miles D, Smith M. MUC1 and the immunobiology of cancer. J Mammary Gland Biol Neoplasia 2002;7:209-21.

(42) Latza U, Niedobitek G, Schwarting R, Nekarda H, Stein H. Ber-EP4: New monoclonal antibody which distinguishes epithelia from mesothelia. J Clin Pathol 1990;43:213-19.

(43) Gompel A, Martin A, Simon P, Schoevaert D, Plu-Bureau G, Hugol D, Audouin J, Leygue E, Truc JB, Poitout P. Epidermal growth factor receptor and c-erbB-2 expression in normal breast tissue during the menstrual cycle. Breast Cancer Res Treat 1996;38:227-35.

(44) Purkis PE, Steel JB, Mackenzie IC, Nathrath WBJ, Leigh IM, Lane EB. Antibody markers of basal cells in complex epithelia. J Cell Sci 1990;97:39-50.

(45) Rudland PS, Hughes CM. Immunocytochemical identification of cell types in human mammary gland: Variation in cellular markers are dependent on glandular topography and differentiation. J Histochem Cytochem 1989;37:1087-100.
(46) Moll R, Franke WW, Schiller DL. The catalogue of human cytokeratins: Patterns of expression in normal epithelial, tumors and cultured cells. Cell 1982;31:11-24.

(47) Edwards PAW, Brooks IM. Antigenic subsets of human breast epithelial cells distinguished by monoclonal antibodies. J Histochem Cytochem 1984;32:531-37.

(48) Momburg F, Moldenhauer G, Hammerling GJ, Moller P. Immunohistochemical study of the expression of a $\mathrm{M}_{r} 34,000 \mathrm{hu}-$ man epithelium-specific surface glycoprotein in normal and malignant tissues. Cancer Res 1987;47:2883-91.

(49) Pechoux C, Gudjonsson T, Ronnov-Jessen L, Bissell MJ, Petersen OW. Human mammary luminal cells contain progenitors to myoepithelial cells. Dev Biol 1999;206:88-99.

(50) Idris N, Carothers Carraway CA, Carraway KL. Differential localization of erbB2 in different tissues of the rat female reproductive tract: Implications for the use of specific antibodies for erbB2 analysis. J Cell Physiol 2001;189:162-70.

(51) Stingl J, Emerman JT, Eaves CJ. Enzymatic dissociation and culture of normal human mammary tissue to detect progenitor activity. In: Helgason CD and Miller CL, editors. Methods in molecular biology: Basic cell culture protocols, Vol 290, 3rd ed. Totowa (NJ): Humana Press; 2004. p. 249-64.

(52) Russo J, Mills MJ, Moussalli MJ, Russo IH. Influence of human breast development on the growth properties of primary cultures. In Vitro Cell Dev Biol 1989;25:643-49.

(53) Romanov SR, Kozakiewicz, BK, Holst CR, Stampfer MR, Haupt LM and Tlsty TD. Normal human mammary epithelial cells spontaneously escape senescence and acquire genomic changes. Nature 2001;409:633-37.

(54) Karsten U, Papsdorf F, Pauly A, Vojtesek B, Moll R, Lane EB, Clausen H, Stosiek P, Kasper M. Subtypes of non-transformed human mammary epithelial cells cultured in vitro: Histo-blood group antigen $\mathrm{H}$ type 2 defines basal cell-derived cells. Differentiation 1993;54:55-66.

(55) Stingl J. in vitro phenotypic and functional characterization of breast epithelial progenitors present in the normal adult human breast. PhD Thesis, Department of Anatomy, University of British Columbia, 2000.

(56) Petersen OW, van Deurs B. Growth factor control of myoepithelial-cell differentiation in cultures of human mammary gland. Differentiation 1998;39:197-215.

(57) Schaefer FV, Custer RP, Sorof S. Squamous metaplasia in human breast culture: Induction by cyclic adenine nucleotide and prostaglandins, and influence of menstrual cycle. Cancer Res 1983;43:279-86.

(58) Tlsty TD, Romanov SR, Kozakiewicz BK, Holst CR, Haupt LM, Crawford YG. Loss of chromosomal integrity in human mammary epithelial cells subsequent to escape from senescence. J Mammary Gland Biol Neoplasia 2001;6:235-43.

(59) Dundas SR, Ormerod MG, Gusterson BA, O'Hare MJ. Characterization of luminal and basal cells flow-sorted from the adult rat mammary parenchyma. J Cell Sci 1991;100:459_ 71.

(60) Smalley MJ, Titley J, O'Hare MH. Clonal characterization of mouse mammary luminal epithelial and myoepithelial cells separated by fluorescence-activated cell sorting. In Vitro Cell Dev Biol Anim 1998;34:711-21.

(61) Smalley MJ, Titley J, Paterson H, Perusinghe N, Clarke C, O'Hare MJ. Differentiation of separated mouse mammary luminal epithelial and myoepithelial cells cultured on EHS matrix analyzed by indirect immunoflourescence of cytoskeletal antigens. J Histochem Cytochem 1999;47:1513-24. 
(62) Ethier SP, Mahacek ML, Gullick WJ, Frank TJ, Weber BL. Differential isolation of normal luminal mammary epithelial cells and breast cancer cells from primary and metastatic sites using selective media. Cancer Res 1993;53:627-35.

(63) Ethier SP. Human breast cancer cell lines as models of growth regulation and disease progression. J Mammary Gland Biol Neoplasia 1996;1:111-21.

(64) Gomm JJ, Coope RC, Browne PJ, Coombes RC. Separated human breast epithelial and myoepithelial cells have different growth requirements in vitro but can reconstitute normal breast lobuloalveolar structure. J Cell Physiol 1997;171:1119.

(65) Papini S, Cecchetti D, Campani D, Fitzgerald W, Grivel JC, Chen S, Margolis I, Revoltella RP. Isolation and clonal analysis of human epidermal keratinocyte stem cells in long-term culture. Stem Cells 2003;21:481-94.

(66) Sauvageau G, Iscove NN, Humphries RK. in vitro and in vivo expansion of hematopoietic stem cells. Oncogene 2004;23:7223-32.

(67) Sherley JL. Asymmetric cell kinetics genes: the key to expansion of adult stem cells in culture. Stem Cells 2002;20:56172.

(68) Lee HS, Crane GG, Merok JR, Tunstead JR, Hatch NL, Panchalingam K, Powers MJ, Griffith LG, Sherley JL. Clonal expansion of adult rat hepatic stem cell lines by suppression of asymmetric cell kinetics (SACK). Biotech Bioeng 2003;83:760-71.

(69) Jones PH, Watt FM. Separation of human epidermal stem cells from transit amplifying cells on the basis of differences in integrin function and expression. Cell 1993;73:713-24.

(70) Jones PH, Harper S, Watt FM. Stem cell patterning and fate in human epidermis. Cell 1995;80:83-93.

(71) Reynolds BA, Weiss S. Generation of neurons and astrocytes from isolated cells of the adult mammalian central nervous system. Science 1992;255:707-10.

(72) Rietze RL, Valcanis H, Brooker GF, Thomas T, Voss AK, Bartlett PF. Purification of a pluripotent neural stem cell from the adult mouse brain. Nature 2001;412:73639.

(73) Toma JG, Akhaven M, Fernandes KJ, Barnabe-Heider F, Sadikot A, Kaplan DR, Miller FD. Isolation of multipotent adult stem cells from the dermis of mammalian skin. Nature Cell Biol 2001;3:778-84.
(74) Reya T, Duncan AW, Ailles L, Domen J, Scherer DC, Willert K, Hintz L, Nusse R, Weissman IL. A role for Wnt signaling in self-renewal of haematopoietic stem cels. Nature 2003;423:409-14.

(75) Ehmann UK, DeVries JT, Chen MS, Adamos AA, Guzman RC, Omary MB. An in vitro model of epithelial cell growth stimulation in the rodent mammary gland. Cell Prolif 2003;36:177-90.

(76) Gudjonsson T, Ronnov-Jessen L, Villadsen R, Rank F, Bissell MJ, Petersen OW. Normal and tumor-derived myoepithelial cells differ in their ability to interact with luminal breast epithelial cells for polarity and basement membrane deposition. J Cell Sci 2002;115:39-50.

(77) Hirai Y, Lochter A, Galosy S, Koshida S, Niwa S, Bissell MJ. Epimorphin functions as a key morphoregulator for mammary epithelial cells. J Cell Biol 1998;140:159-69.

(78) Daniel CW, Young LJT, Medina D, DeOme KB. The influence of mammogenic hormones on serially transplanted mouse mammary gland. Exp Gerentol 1971;6:95-101.

(79) Niranjan B, Buluwela L, Yant J, Perusinghe N, Atherton A, Phippard D, Dale T, Gusterson B, Kamalati T. HGF/SF: A potent cytokine for mammary growth, morphogenesis and development. Development 1995;121:2897-908.

(80) Daniel CW, Silberstein GB, Strickland P. Direct action of $17 \beta$-estradiol on mouse mammary ducts analyzed by sustained release implants and steriod autoradiography. Cancer Res 1987;47:6052-57.

(81) Parmar H, Young P, Emerman JT, Neve RM, Dairkee S, Cunha GR. Endocrinology 2002;143:4886-96.

(82) Al-Hajj M, Wicha MS, Benito-Hernandez A, Morrison SJ, Clarke MF. Prospective identification of tumorigenic breast cancer cells. Proc Natl Acad Sci USA 2003;100:3983-88.

(83) Perou CM, Sorlie T, Eisen MB, van de Rijn M, Jeffrey SS, Rees CA, Pollack JR, Ross DT, Johnsen H, Akslen LA, Fluge O, Pergamenschikov A, Williams C, Zhu SX, Lonning PE, Borresen-Dale AL, Brown PO, Botstein D. Molecular portraits of human breast tumors. Nature 2000;406:747-52.

(84) Sorlie T, Perou CM, Tibshirani R, Aas T, Geisler S, Johnsen $\mathrm{H}$, Hastie T, Eisen MB, van de Rijn M, Jeffrey SS, Thorsen T, Quist H, Matese JC, Brown PO, Botstein D, Eystein Lonning $\mathrm{P}$, Borresen-Dale AL. Gene expression patterns of breast carcinomas distinguish tumor subclasses with clinical implications. Proc Natl Acad Sci USA 2001;98:10869-74. 